\section{Is primary Sjögren's syndrome an orphan disease? A critical appraisal of prevalence studies in Europe}

A meta-analysis of epidemiological studies in primary Sjögren's syndrome (pSS) has been recently published in the Annals of the Rheumatic Diseases by Qin et al. ${ }^{1}$ According to this study, the estimated prevalence of pSS worldwide is 60.82 per 100000 inhabitants, or 1 person in 1644. Thus, the prevalence of pSS would not fit in with the definition of a rare disease. However, the extraordinary heterogeneity of the results between the different included studies is striking: the prevalence of this disease in single studies ranges from 11.34 to 3790.09 per 100000 persons.

In Europe, a disease is considered rare when it affects less than one person per 2000: this is the definition of an orphan disease. To date, 6000 to 7000 rare diseases have been recognised, but this figure is constantly evolving with scientific knowledge (http://www.orpha.net). Many are genetic diseases, some are infectious or autoimmune. The recognition of a disease as rare has important implications, most importantly, for the development of new therapies. Indeed, the European Parliament and the Council adopted regulation (CE) No. 141/2000 on orphan drugs in 1999, which encourages the pharmaceutical and biotechnological industry to carry out research on and develop drugs to treat orphan diseases.

pSS is a systemic autoimmune disease, mainly characterised by sicca symptoms (eye and mouth dryness), intense fatigue, inflammatory infiltrate of exocrine glands and production of auto-antibodies. These symptoms are nonspecific and several differential diagnoses have to be excluded. ${ }^{2}$ Numerous classification criteria for pSS have been proposed, but the most widely used are those issued by the American-European Study Group (AECG) in 2002. ${ }^{3}$ The different criteria are not equivalent and may profoundly affect the results of epidemiological studies. For example, in a study from Turkey on adult women, the prevalence of pSS fell from $0.49 \%$ using the preliminary European criteria ${ }^{4}$ to $0.30 \%$ according to the AECG criteria. ${ }^{5}$ New classification criteria were proposed in 2012 and endorsed by the American College of Rheumatology, ${ }^{6}$ but they are not consensual,,$^{7-10}$ and no epidemiological study has been published to date using these criteria.

Several factors influence the quality of a prevalence study and the accuracy of its results: the case-finding method (which detects potential cases), the methodologies used to ascertain these cases (only patients who really have the disease are included) and the definition and size of the background population. Case-finding methods can be the analysis of administrative databases or hospital medical records (which can be considered as sensitive methods) or from responses to questionnaires sent to a selected population. In questionnaire-based studies, patients with mild symptoms, who never consulted for that reason, may be newly diagnosed, artificially increasing the prevalence of the disease. Conversely, analysis of administrative databases or hospital medical records detects patients with an actual clinical diagnosis. The efficacy of case-finding is improved when several methods are used in parallel.

To assess the cases, the opinion of the patient or physician, or the administrative coding system, is not considered reliable. Instead, cases must be defined by reviewing medical charts using a validated set of criteria, such as the AECG criteria. The background population should not be specific groups of patients or hospital-based charts but, rather, should concern the whole population within a precise geographical area, using administrative data (population-based studies). The size of this population must be large enough to allow accurate estimation of the prevalence of the disease. Sample surveys, which usually use questionnaires to select part of a target population, are dampened by low response rates and selection bias. Furthermore, the prevalence of a disease may be region dependent.

Thus, to accurately estimate the prevalence of pSS in Europe, we have to focus on studies using good methodology (population-based study, effective case-finding methods, ascertainment of cases using AECG criteria, large background population) and that have been performed exclusively in European countries. Only three studies respond to these criteria: one was performed in Greece, ${ }^{11}$ one in Norway ${ }^{12}$ and the third in France $^{13}$ (table 1). When their results are combined, we estimate the prevalence of pSS in Europe to be 38.95/100 000, or one person per 2567. Of note, the methodology of Maldini's French study is the most robust as it uses five case-finding data sources and capture-recapture methods and gives the lowest prevalence figure $(11.34 / 10000$, or one person per 8818$) .{ }^{13}$

To conclude, the estimated prevalence of pSS in Europe is far lower than suggested by older sample surveys, and is probably below the 1/2000 threshold to define a rare disease. Other robust epidemiological studies are warranted to definitively confirm these preliminary results.

\section{Divi Cornec, ${ }^{1}$ Laurent Chiche ${ }^{2}$}

${ }^{1}$ Service de Rhumatologie, CHRU Brest, ESPRI/ERI29, Université de Bretagne Occidentale, Brest, France

${ }^{2}$ Service de Médecine Interne, Hôpital de la Conception, AP-HM, Université Aix-Marseille, Marseille, France

Correspondence to Dr Divi Cornec, Service de Rhumatologie, Hôpital de la Cavale Blanche, BP 824, Brest, Cedex F 29609, France; divi.cornec@chu-brest.fr

\begin{tabular}{|c|c|c|c|c|c|}
\hline Reference & Region & Case-finding methods & Cases & Reference population & (cases/100 000) \\
\hline Alamanos et a $\left.\right|^{11}$ & Greece (North-west) & $\begin{array}{l}\text { Medical record search } \\
\text { Personal registry physicians }\end{array}$ & 422 & 488435 & 86.40 \\
\hline Gøransson et $a l^{12}$ & Norway & $\begin{array}{l}\text { Medical record search } \\
\text { Personal registry physician }\end{array}$ & 424 & 852342 & 49.75 \\
\hline Maldini et $a l^{13}$ & France & $\begin{array}{l}\text { Capture/recapture National health } \\
\text { insurance and National patient support } \\
\text { and private laboratories }\end{array}$ & 133 & 1172482 & 11.34 \\
\hline Overall & & & 979 & 2513259 & 38.95 \\
\hline
\end{tabular}


Acknowledgements We thank Marine Berro (OrphanDev, Marseille) for thoughtful discussions about the epidemiology of rare diseases.

Contributors DC and LC equally contributed to the conception and the drafting of the manuscript.

Competing interests None.

Provenance and peer review Not commissioned; internally peer reviewed.

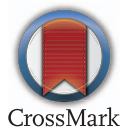

To cite Cornec D, Chiche L. Ann Rheum Dis 2015;74:e25.

Received 24 October 2014

Accepted 26 October 2014

Published Online First 7 November 2014

\section{(5) Linked}

http://dx.doi.org/10.1136/annrheumdis-2014-206885

Ann Rheum Dis 2015;74:e25. doi:10.1136/annrheumdis-2014-206860

\section{REFERENCES}

1 Qin B, Wang J, Yang Z, et al. Epidemiology of primary Sjögren's syndrome: a systematic review and meta-analysis. Ann Rheum Dis. Published Online First: 17 June 2014. doi:10.1136/annrheumdis-2014-205375

2 Cornec D, Saraux A, Jousse-Joulin $S$, et al. The differential diagnosis of dry eyes, dry mouth, and parotidomegaly: a comprehensive review. Clin Rev Allergy Immunol. Published Online First: 21 June 2014. doi:10.1007/s12016-014-8431-1
3 Vitali C, Bombardieri S, Jonsson R, et al. Classification criteria for Sjögren's syndrome: a revised version of the European criteria proposed by the American-European Consensus Group. Ann Rheum Dis 2002;61:554-8.

4 Vitali C, Bombardieri S, Moutsopoulos HM, et al. Preliminary criteria for the classification of Sjögren's syndrome. Results of a prospective concerted action supported by the European Community. Arthritis Rheum 1993;36:340-7.

5 Birlik M, Akar S, Gurler O, et al. Prevalence of primary Sjogren's syndrome in Turkey: a population-based epidemiological study. Int I Clin Pract 2009;63: 954-61.

6 Shiboski SC, Shiboski CH, Criswell LA, et al. American College of Rheumatology classification criteria for Sjögren's syndrome: a data-driven, expert consensus approach in the Sjögren's International Collaborative Clinical Alliance Cohort. Arthritis Care Res 2012:64:475-87.

7 Vitali C, Bootsma H, Bowman SJ, et al. Classification criteria for Sjogren's syndrome: we actually need to definitively resolve the long debate on the issue. Ann Rheum Dis 2013;72:476-8.

8 Rasmussen A, Ice JA, Li H, et al. Comparison of the American-European Consensus Group Sjögren's syndrome classification criteria to newly proposed American College of Rheumatology criteria in a large, carefully characterised sicca cohort. Ann Rheum Dis 2014;73:31-8.

9 Bowman SJ, Fox RI. Classification criteria for Sjogren's syndrome: nothing ever stands still! Ann Rheum Dis 2014;73:1-2.

10 Cornec D, Saraux A, Cochener B, et al. Level of agreement between 2002 American-European Consensus Group and 2012 American College of Rheumatology classification criteria for Sjögren's syndrome and reasons for discrepancies. Arthritis Res Ther 2014;16:R74.

11 Alamanos Y, Tsifetaki N, Voulgari PV, et al. Epidemiology of primary Sjögren's syndrome in north-west Greece, 1982-2003. Rheumatol Oxf Engl 2006;45: 187-91.

12 Gøransson L, Haldorsen K, Brun J, et al. The point prevalence of clinically relevant primary Sjögren's syndrome in two Norwegian counties. Scand I Rheumatol 2011:40:221-4.

13 Maldini C, Seror R, Fain O, et al. Epidemiology of primary Sjögren's syndrome in a French multiracial/multiethnic area. Arthritis Care Res 2014;66:454-63. 